\section{Cause of a recent period of cool weather in New England.}

From Aug. 15 to Aug. 23 the weather in New England was quite cool and pleasant. This cool period culminated on the night of the $22 \mathrm{~d}$, when the temperature at the Boston signal office sank as low as $49^{\circ}$. On the signal service weather-chart of the morning of Aug. 23, it is found that the temperature was higher all around New England (north, east, south, and west) than in New England itself. Over New England the sky was clear, and the air was blowing out from this region in every direction, on the east side toward a storm which is central on the ocean, and on the west side toward a storm which is central in the lake region. Whence, then, came this cool air? for it had previously been quite warm. It evidently could not have been imported from abroad was it, then, due to a descent of cool air from above? This is hardly possible, since it was found, at 11 P.M. of the 22d, that the temperature on Mount Washington was $51^{\circ}$, while at the nearest lower stations Portland and Boston - the temperature was $56^{\circ}$, and on top of Blue Hill 51 . At 7 A.M. of the $23 d$ the conditions of temperature were almost the same, except that the temperature had risen slightly at every station but Boston. If the air had descended from the height of Mount Washington, it is well known that its compression would have heated it much higher than the temperature was found to be at lower stations, unless this heating had been counteracted by some other cause. On top of Blue Hill the lowest temperature recorded by a self-registering minimum thermometer on the night of Aug. 22 was only $50.5^{\circ}$; while, at a base station four hundred feet lower, the temperature fell to $44^{\circ}$; and in Boston, nearly six hundred feet lower and ten miles distant, the temperature fell to $49^{\circ}$. The thermometers were alike, and exposed in the same manner. The air evidently descended over New England from above, otherwise the wind could not have blown out in every direction; but the statistics above show that its coolness could not have been due to this cause, since it was cooler at the earth's surface than a little distance above it The air, as was to be expected on account of its descent from above, was clear and dry, the absolute humidity being lower than at any time during the month except on the night of Aug. 15, when almost identical conditions prevailed. Here we no doubt find the cause of the coolness. Tyndall's experiments on the effect of aqueous vapor in intercepting radiation from bodies of low temperature like the earth led him to assert, that, if the blanket of aqueous vapor over England were removed for one summer's night, the whole island would by morning be held in the iron grip of frost, on account of the rapid radiation from the earth's surface which such conditions would permit. Even the more intense insolation by day at such time would be counteracted by the rapid radiation into space, as shown at elevated parts of the earth's surface. This serves to explain the cool period lasting several days in New England; and this cool period seems to substantiate the view recently advanced, that the cold in anticyclones (or areas of high pressure) is due to radiation from the earth's surface, which is favored by the clear, dry atmosphere accompanying these areas. Tyndall, Hann, and Woeik of have adduced evidence of this in Europe, and Mr. Dewey in this country (see Amer. met. journ., May, 1886).

Blue Hill meteor. observ., Aug. 30.
Dr. Orton's Ohio gas and oil report.

I have been carefully studying my friend Dr. Orton's admirable and most valuable report on the Findlay, Bowling Green, and Lima wells, an advanced summary of which you published in the issue of Science for June 25. Having been absent from my office, I am ignorant as to whether your subsequent issues contain notices or criticisms of Dr. Orton's facts and views, which I esteem not only historical, but marking an era in our knowledge of the subject. I run some risk, therefore, of offering considerations which others may have anticipated; but two or three of these considerations deserve attention in the present stage of our investigations.

I trust that all geologists will sympathize with me in heartily cheering Dr. Orton's skilful insertion of the long-waited for keystone in the areh of the demonstration of the origin of oil. I am ashamed of my own stupidity in not finding and fixing in its place this keystone myself. I have been seeking it for years, asking myself continually how the decomposing organic matter of the seashores and marshes could be retained by the sands and shales until sufficiently protected from complete oxidation. I have repeatedly put this question to other geologists, but never received an answer of any kind; apparently because so few of them accepted the in situ origin of rock-oil, and therefore seeing no value in the question, and no need for an answer to it. Dr. Orton is the first geologist to appreciate the value of Dr. Leidy's observation of the petroleum-mud-layer at the mouth of the Schuylkill River; and his generalization from it is one of the best and broadest ever made in our branch of science. It accounts satisfactorily for the preservation of rock-oils in every formation, of every geological age, all over the world; subject, however, locally or regionally, to subsequent change or destruction. The eruptive rocks (lavas proper) are the only formations not charged with organic matter. Even the tufas, swept by the wind into the sea, must hold the remains of animal air-life and plant pollen. The winds are forever transferring dead and living organisms from place to place, and every rain washes them to the surface of the land and sea to be locked up in clay formations. However different the regional conditions, the process is continual and the results identical every where. Compare the Levant with the Red Sea. Each is as large as our Appalachian belt from Canada to the Gulf of Mexico. The one, however, is a reservoir of Nile deposits, - an extension of the Delta under sealevel, - replete with the original stuff of rock-oil. The other is a reservoir of incalculable quantities of wind-deposits, mixed with equally incalculable quantities of tropical animal and vegetable organic stuff. If any one still doubts the in situ theory, let him try to invent any other for the vast expanse of petroleum ground on both sides of the Caspian, and of course including the bed of that sea. There, also, we see going on at present the slow process of the loss of rock-oil from a formation which was originally charged with it; and that without any great structural disturbance. In Galicia, in Lombardy, on the other hand, we see the process of loss nearly finished under conditions of structural disturbance so great as to make the dips vertical. If Oken had been a geologist, and were living now, he would probably assert in his next treatise - and with a certain magnificent truthfulness - that the whole crust of the globe consists only of oiled clay, whether siliceous, ferruginous, 
or calcareous, - here, in its original condition ; there, oxidized and dried ; in another place, crystallized and cleansed. Fortunately the Okens are not all dead; but their generalizations are restrained by a wise caution as to the genuineness of facts, and regulated by measurements. Dr. Orton's report proves this in a most satisfactory manner - if it needed pronf.

The difference between the Pennsylvania and north-west Ohio oil and gas regions is fourfold : $1^{\circ}$, one is Devonian, the other Silurian ; $2^{\circ}$, one is sandstone, the other limestone; $3^{\circ}$, one is decidedly waved, the other almost on a dead level; $4^{\circ}$ (and this is what I wish specially to discuss), the one is non-cavernous, the other cavernous.

Thirty years age I began to insist upon the geological (especially the topographical) importance of the underground chemical and mechanical erosion of the limestone formations of the world. I was led to this by my first field-work in the Silurian valleys of Pennsylvania and my early study of the blue-grass country of Kentucky. I saw that the eastern and western coal-fields had been separated by the fallingin of the roofs of myriads of mammoth caves in the Trenton limestones, preceded by the same process at the outcrops of the cavernous subcarboniferous limestones. I have always opposed the notion of the early age of the Cincinnati uplift. The nonconformity in middle Ohio, and that around Nashville, are important facts, but merely mark two out of many local and temporary variations in the general downward movement, which was otherwise uninterrupted from Silurian times to the end of the coal-measure age. It was not until then that the great upward and plicating movement took place, which started the erosion of the United States area. The principal rôle in the erosion from that time until now has been played by the limestone formations, under the solvent action of drainage-waters acting everywhere through them, down to and for some depth below sea-level. Everybody knows the result in the great Appalachian valleys. Everybody knows how the Ohio valley region is undermined. I venture little in asserting that the new oil and gas region of northwestern Ohio is thus undermined. This makes it essentially characteristically different from the Pennsylvania, West Virginia, and eastern Ohio oil and gas region. If the numerous wells bored at Findlay and in the twenty-seven counties of north-western Ohio have none of them struck through the roof of a mammoth cave, that negative argument is of no force when one calculates the chances of a well being drilled directly over such a cave. These caverns are the great underground drainage-channels. They correspond to the large streams on the earth's surface. What would be the chances for and against a man in a balloon at night dropping a bag of ballast into a river? A river, however, is a mile, half a mile, a furlong wide; a cavern cannot be more than fifty or one hundred feet wide. On the other hand, the caves are probably somewhat more numerous than the large surface-streams, but not much. Certainly no one will venture to deny the undermined condition of Ohio, until as many thousand wells have been bored into the Trenton formation as have been bored into the Pennsylvania Devonians.

But the underground drainage is only collected into and passed through the mammoth caves to some exit. Its collection takes place through the infinite multitude of vertical fissures which cut up the whole limestone formation into blocks; and these fissures are all widened by chemical solution. The whole Trenton underground of Ohio must be like the Roman arsenal works at Baix, - a sort of crypt, in which water stands now at a level in the caves and fissures, because it can find no rapid issue at sealevel. In central Kentucky the cave-waters flow, because they can issue in the bed of the Ohio River; but in north-western Ohio the top of the Trenton Dr. Orton shows to lie from three hundred to nine hundred feet below sea-level (i.e.. in round numbers, from eight hundred and fifty feet to fourteen hundred and fifty feet below the surface of Lake Erie), and therefore no flow is possible. The water must be standing water: the oil will therefore rise to its surface, and the gas press upon the surface of the oil, and over the whole extent of communicating fissures and caves equally.

But how could caves be formed at such a depth beneath sea-level? Standing water may corrode, but cannot erode. No one dreams that our Silurian cares in Pennsylvania follow the limestone strata many thousands of feet beneath sea-level under the great synclinals. No; but there are some wonderful facts for all that. There is a stream in Brush valley which sinks and flows under Nittany Mountain to rise in Nittany valley, where it drives a large mill. Sawdust and other things - a miller's hat among them - have made the underground voyage. The top of the limestone lies beneath the mountain two thousand feet lower than its outcrop and one thousand feet beneath ocean-level. It is an inverted siphon, with one mouth several hundred feet higher than the other; the confining top wall of the siphon being impervious Utica clay slate. At the Roman baths near Zurich (Baden in Aargau) river-water descends from a vertical outcrop to a depth of three thousand feet, and ascends, mineralized and heated, to the bath houses. The hot springs of Virginia are similar deep inverted limestone siphons.

In fuct, there is no such thing as standing water anywhere. All water flows. Mere evaporation at one end of a canal will cause a current to set from the other end. Hydraulic pressure from the surface of middle Ohio will suffice to produce a universal lateral and upward water movement in northern Ohio, the Trenton sinking in that direction. If the currents thus induced be infinitely slow and gentle, nevertheless there has been an infinite amount of geological time (since the coal age) for them to effect their underground erosion in.

To all this must be added the great depth of the real rock-basin of Lake Erie. It is now only two hundred or three hundred feet deep; but who knows the thickness of its lining deposits? It has been receiving the inflow of Michigan, Indiana, Ohio, Pennsylvania, and the Canada peninsula for an unknown length of time, and, in addition to previous deposits, the glacial drift and modern river-muds. My belief is that its mother rock-bottom is excavated to a depth greater than the deepest wells of the new oil and gas region; and, if so, then the origin of the system of manmoth caves and fissures which hold the salt water, oil, and gas of north-western Ohio is relieved of difficulties. The water which is now nearly stag. nant, flowed then freely to its natural outlets; the underground erosion which is now infinitesimally feeble, proceeded then energetically, at a rapid rate and on a grand scale.

What I wish to draw attention to is this : granting 
a cavernous condition of the Trenton in Obio, then Dr. Orton's terrace structure of the top of the Trenton becomes of value as indicating slopes in the general plane of the cavernous part of the formation. By this I mean to indicate the probability that the whole formation is not cavernous to an equal extent throughout (from top to bottom), but that certain members of the mass are more soluble than the rest. In Pennsylvania the Trenton itself is not cavernous on a grand scale : our sinking springs are along the outcrop of the passage-beds at the bottom of the Trenton and Bird's-eye and top of the calciferous. The whole formation in front of the Alleghany Mountains is between six and seven thousand feet thick. The uppermost thousand feet is very compact and non-mangesian; the underlying mass is composed of alternate layers of limestone and dolomite, with some low-lying calcareous sandstone groups. Dr. Orton reports the formation in Ohio 'magnesian, of a fair character throughout most of its extent,' but ' somewhat siliceous in some of the drillings.' It will be an important item of investigation, how far the cavernous horizon in Ohio corresponds to that in Pennsylvania, where the formation is ten times as thick as in Ohio. Dr. Orton inadvertently remarks (p. 18) that 'there is no warrant for assuming its universality as a limestone' under the country between middle Obio and middle Pennsylvania. But I am sure that he will revise the remark when he reflects that a formation which is 'universally limestone' from Tennessee to the Manitoulin Islands in a north and south direction, and is universally limestone along the whole Appalachian belt from Alabama to New York, cannot possibly be any thing else than limestone under the intermediate region of the bituminous coal-measures. If there is any reasoning from the exposed to the concealed in geology, all geologists must feel sure - quite sure - that the lower Silurian formation No. II. must underlie Wheeling and Pittsburgh as a limestone formation, non-magnesian at top, magnesian at middle and bottom, at least two thousand if not three thousand feet thick, and at a depth of, say, ten thousand feet beneath the present surface.

But I have been led on to a much greater length than I expected, by the importance of the subject, to the new gas and oil industry of Ohio. I cannot trespass longer on your space with the obvious applications of what I have adduced above to the vexed questions of local capriciousness, etc., in the new oil and gas field.

Philadelphia, Sept. 1.

\section{The law of volumes in chemistry.}

The questions regarding the so-called molecular weights and volumes of liquids and solids, which are now attracting the attention of chemists, can, I think, be better understood if we keep in mind the principles enunciated by the writer in 1853, that "the doctrine of chemical equivalents is that of the equivalency of volumes," and that "the simple relations of volumes which Gay-Lussac pointed out in the chemical changes of gases apply to all liquid and solid species ;" so that "the application of the atomic hypothesis to explain the law of definite proportions becomes wholly unnecessary." In further illustration of this view, it was said in 1867 that "the gas or vapor of a volatile body constitutes a species distinct from the same body in a liquid or solid state; and the liquid and solid species themselves often [probably always] constitute two distinct species of different equivalent weights." From this it follows that freezing, melting, and vaporization are chemical changes. The union of many volumes of a vapor or gas in a single volume of a liquid or a solid is a process of chemical combination, while vaporization is chemical decomposition. Such decomposition is either with or without specific difference, and examples of these two modes are seen respectively in heterogeneous dissociation and in integral volatilization, which latter is the breaking-up or dissociation of a polymeric species into simpler forms having the same centesimal composition. Both of these processes are subordinated to the same laws of pressure and temperature, and involve similar thermic changes in the relations of the bodies concerned. In this enlarged conception of the chemical process we find a solution of the problems above named, and an explanation of the distinction which has been made between 'the chemical molecule' and 'the molecule of the physicist.' That the latter has a much less simple constitution than the former, as calculated from the results of chemical analysis and from vapordensity, has been long maintained alike on dynamical and chemical grounds. It is discussed by the writer in 1853 in the essay already quoted, entitled 'The theory of chemical changes and equivalent.volumes,' 1 and again in the late paper of Spencer Pickering in the Chemical news for November, 1885.

If, then, as maintained by the writer, the law of volumes is universal, and if the production of liquids and solids by the condensation of vapors is a process of chemical union giving rise to polymerids, the equivalent weights of which are as much more elevated as their densities are greater than those of the vapors which combine to form them, the hypothesis of atoms and molecules, as applied to explain the law of definite proportions and the chemical process, is not only unnecessary, but misleading. According to this hypothesis, which supposes molecules to be built up of atoms, and masses of molecules, the different ratios in unlike species between the combining weight of the chemical unit or molecule (as deduced from analysis and from vapor-density; $H=1.0$ ) and the specific gravity of the mass are supposed to represent the relative dimensions of the molecule. Hence the values got by dividing these combining weights by the specific gravity have been called ' molecular volumes.' The number of such molecules required to build up a physical molecule of constant volum $\theta$ would, according to this hypothesis, be inversely as their size. If, however, as all the phenomena of chemistry show, the formation of higher and more complex species is by condensation, or, in other words, by identification of volume, and not by juxtaposition, it follows that the so-called molecular volumes are really the number's representing the relative amount of contraction of the respective substances in passing from the gaseous to the liquid or solid state, and are the reciprocals of the coefficient of condensation of the assumed chemical units. If steam at $100^{\circ} \mathrm{C}$. and 760 millimetres pressure, with a formula as deduced from its density of $\mathrm{H}_{2} \mathrm{O}$, and a combining weight of 18 , is converted into water at the same temperature, 1,628 volumes of it are condensed into a single volume, having a specific gravity of 0.9588 , which at $4^{\circ} \mathrm{C}$. becomes 1.0000 . Water is

1 See the author's ' Uhemical and geological essays,' pp. 426-437, and, further, ibid., pp. 453-458. 